\title{
LIQUIDITY OF EUROPEAN REAL ESTATE EQUITIES: REITS AND REOCS
}

\author{
Jaakko NISKANEN $1 \bowtie$ and Heidi FALKENBACH ${ }^{2}$ \\ ${ }^{1}$ Aalto University School of Science and Technology, Real Estate Research Group, PO Box \\ 11200, FI-00076 Aalto, Finland \\ E-mail: jaakko.niskanen@hut.fi \\ 2 Aalto University School of Science and Technology, Real Estate Research Group, PO Box \\ 11200, FI-00076 Aalto, Finland \\ E-mail: heidi.falkenbach.@hut.fi
}

Received 2 February 2011; accepted 9 May 2011

\begin{abstract}
Listed real estate companies can be divided into two categories: real estate operating companies (REOCs) and real estate investment trusts (REITs). REOCs have been around for quite a while, whereas REITs are a somewhat new phenomenon in Europe, the main differences pertaining to permissible activities and taxation. This paper studies the relative differences of REOCs and REITs in terms of liquidity: Also asset returns, volatility and correlation to other equities are assessed. The liquidity tests performed reveal REITs to be significantly more liquid than REOCs, potentially due to restrictions regarding REIT ownership structure. Ceteris paribus, superior REIT liquidity implies REITs constitute a preferred investment vehicle.
\end{abstract}

KEYWORDS: Real estate investment trusts; Real estate operating companies; Real estate equities; Real estate liquidity; Real estate investing

\section{INTRODUCTION}

The value of global real estate assets reaches over 19,000 billion dollars, the dollar value of European real estate assets amounting to nearly 8,000 billion. To put the figures in a perspective, the value of the whole global stock market (listed, all industries) amounts to about 44,000 billion dollars. It follows that the value of all real estate assets, private and public combined, reaches almost $44 \%$ of the value of all listed stock market assets in the world (EPRA, 2010; Table 1). Thus, real estate constitutes an important share of the investment portfolio of any well-diversified investor.
Table 1. Global real estate and stock values

\begin{tabular}{lll}
\hline Real estate, stock values (\$bn) & & \\
\hline Total real estate assets, world & $\$$ & 19,269 \\
Total real estate assets, Europe & $\$$ & 7,815 \\
$\begin{array}{l}\text { Total listed real estate assets, } \\
\text { world }\end{array}$ & $\$$ & 1,159 \\
$\begin{array}{l}\text { Total listed real estate assets, } \\
\text { Europe }\end{array}$ & $\$$ & 249 \\
REOCs Europe (239 companies) & $\$$ & 167 \\
REITs, Europe (127 companies) & $\$$ & 82 \\
Total stock market value, world & $\$$ & 43,539 \\
Total stock market value, Europe & $\$$ & 11,136 \\
\hline
\end{tabular}

In general, two major ways in which investors can invest in real estate can be distinguished: private and public (Seiler et al., 1999). 
Private real estate is acquired by investing directly, through property pools, commingled real estate funds (CREFs), syndications or separate accounts managed by real estate professionals. The second category, public real estate, involves the purchase of securitized real estate. The private real estate assets offer a more direct exposure to real estate markets, whereas the listed real estate market helps to solve the problems of investing in non-listed real estate, such as illiquidity, intense management and high unit cost (Sebastian and Schätz, 2010). Listed securitized real estate vehicles also constitute homogeneous and diversified investment assets with low transaction costs (Serrano and Hoesli, 2009). Moreover, listed real estate offers an opportunity to invest into real estate without the problems associated with investing into private real estate, such as information asymmetries and operational risks (Hoesli and Lekander, 2008). Furthermore, the public real estate securities market provides investors with a vehicle to construct international property portfolios without the burden of acquiring, managing and disposing of direct property investments in distant countries with unfamiliar legal, political and market structures.

Since the turn of the millennium, the European real estate market has been subject to substantial changes in financial regulation. The market has traditionally consisted of real estate operating companies (REOCs), but, during the past few years, an increasing number of European countries have adopted legislation regarding real estate investment trusts (REITs), pass-through entities which distribute most of their earnings as dividends to shareholders (Brounen et al., 2009a). In other words, the European listed real estate field now covers two different forms of investment; traditional real estate operating companies (REOCs) and the new form, real estate investment trusts (REITs).

The aim of this study is to analyse the relationship of these two different forms of Eu- ropean real estate stock, primarily in terms of share liquidity as measured by Euro trading volumes and asset turnover ratios. Moreover, of interest is to study the potential implications of the structural differences between the two: REOCs are free to invest their assets as best deemed, whereas the distribution requirements of REITs make internal growth rather challenging. Do REITs and REOCs exhibit differing return characteristics? Should they be viewed as separate vehicles within an asset class (real estate)? These questions are approached through an analysis of asset returns and correlations.

As Dhar and Goetzmann posited in 2005, in addition to relative return performance and the qualities of real estate as portfolio diversifiers in a mixed-asset portfolio, investors in international property shares are also concerned with liquidity. Thus, the liquidity characteristics of European REITs and REOCs, and possible differences therein, are addressed in the paper.

This paper is organized as follows: First, European real estate equities market is discussed. This chapter will present the largest European real estate countries, issues pertaining to regulation etc. in order to provide the reader with an enhanced understanding of the operating environment. In the next chapter, the field of relevant literature to this study is provided. Then, the, data and methodology used in this research are discussed. Thereafter empirical results, along with summary and conclusions, are provided.

\section{EUROPEAN REAL ESTATE EQUITIES}

The European listed real estate market expanded rapidly during the past decade. REOC stocks (no distinguishing regulation from any other equities) have been available in the market for a long time, whereas the REIT market has been growing steadily as a result of several European countries recently introducing spe- 
cific REIT regulations. Today, the number of European countries with special REIT legislation amounts to 14, the largest REIT countries being France, UK and the Netherlands. Altogether, European REITs constitute more than $22 \%$ of global REIT assets (Tables 2 and 3 ).

Table 2. Global REIT market as measured by number and value of REITs

\begin{tabular}{llll}
\hline & $\begin{array}{l}\text { Number } \\
\text { of } \\
\text { REITS }\end{array}$ & $\begin{array}{l}\text { Value of } \\
\text { REITs } \\
(€ b n)\end{array}$ & $\begin{array}{l}\text { Value of } \\
\text { global REIT } \\
\text { market, \% }\end{array}$ \\
\hline Africa & 5 & 2.1 & $0.73 \%$ \\
Americas & 230 & 146.7 & $51.15 \%$ \\
Asia & 109 & 39.8 & $13.88 \%$ \\
Australia & 66 & 34.9 & $12.17 \%$ \\
Europe & 127 & 63.28 & $22.07 \%$ \\
Total & 537 & 286.78 & $100 \%$ \\
\hline
\end{tabular}

Source: EPRA Global REIT Survey (2009)

Now, a clear distinction between European REITs and REOCs has to be made: In order to qualify as a REIT, a real estate company must fulfil certain requirements set forth in national legislation. In return for avoiding taxation on the corporate level, the company must distribute most of its income as dividends. The tax exemption puts the REIT shareholder in a comparable position to those investing in real estate directly or through mutual funds. As opposed to tax-exempt REITs, real estate companies organized as REOCs are subject to corporate tax. REOCs are real estate companies which are either domiciled in countries without REIT legislation or, which have chosen not to opt for REIT status.

The US REIT legislation dates back to the 1960s, whereas the field of European REITs is far more fragmented: This is due to the fact that REIT legislation is always passed on a country level. As a result, there is no common REIT structure within the European Union. Despite some differences in national REIT legislation, the majority of the European REIT structures still exhibit similar features. The characteristics typically exhibited by European REIT structures are discussed in more detail below (as in Eichholtz and Kok, 2007).

Firstly, the main issue in REIT legislation is tax exemption at the corporate level. REIT regimes aim at avoiding taxation of rental income at the corporate level, thus putting the shareholder in a comparable position with an investor owning property directly.

Table 3. The European REIT market in figures

\begin{tabular}{|c|c|c|c|c|c|}
\hline & $\begin{array}{l}\text { REITs } \\
\text { since }\end{array}$ & $\begin{array}{l}\text { Number of } \\
\text { REITS }\end{array}$ & $\begin{array}{l}\text { Value of } \\
\text { REITs (€bn) }\end{array}$ & $\begin{array}{l}\text { Value of European } \\
\text { REIT market, \% }\end{array}$ & $\begin{array}{l}\text { Value of global } \\
\text { REIT market, \% }\end{array}$ \\
\hline Belgium & 1995 & 14 & 4 & $6.32 \%$ & $1.39 \%$ \\
\hline Bulgaria & 2004 & 19 & 0.2 & $0.32 \%$ & $0.07 \%$ \\
\hline Finland & 2009 & & & & \\
\hline France & 2003 & 46 & 32.2 & $50.88 \%$ & $11.23 \%$ \\
\hline Germany & 2007 & 2 & 0.4 & $0.63 \%$ & $0.14 \%$ \\
\hline Greece & 1999 & 2 & 0.5 & $0.79 \%$ & $0.17 \%$ \\
\hline Israel & 2006 & 1 & 0.08 & $0.13 \%$ & $0.03 \%$ \\
\hline Italy & 2007 & 1 & 0.4 & $0.63 \%$ & $0.14 \%$ \\
\hline Lithuania & 2008 & & & & \\
\hline Luxembourg & 2007 & & & & \\
\hline Netherlands & 2003 & 8 & 5.9 & $9.32 \%$ & $2.06 \%$ \\
\hline Spain & 2009 & & & & \\
\hline Turkey & 1995 & 13 & 0.9 & $1.42 \%$ & $0.31 \%$ \\
\hline United Kingdom & 2007 & 21 & 18.7 & $29.55 \%$ & $6.52 \%$ \\
\hline Total & & 127 & 63.28 & $100.00 \%$ & $22.07 \%$ \\
\hline
\end{tabular}

Source: EPRA Global REIT Survey (2009) 
Moreover, REIT tax treatment can be seen analogous to that of mutual funds (exempt from corporate tax). In order to be granted a tax exempt status, REITs are typically subject to distribution requirements. In order to guarantee an ultimate tax payment, REITs must annually deliver a substantial amount of net profits as dividends, typical percentages varying between $80-100 \%$. Moreover, REITs are often faced with Operational restrictions. Typical restrictions entail regulations pertaining to real estate development and investment strategy, especially regarding the assets that qualify for REIT investments) etc.

Furthermore, REITs must follow special leverage restrictions. In most European REIT countries the leverage is restricted to $40-60 \%$ of all assets. Eichholtz and Kok (2007) argue that leverage restrictions put REITs into a disadvantageous position in comparison with other property investments: The amount of debt allowed in REIT operations is restricted unlike in the case of REOCs. REIT specific shareholder requirements are set forth to ensure a proper use of REIT structure and share liquidity; companies with tax transparent structure often have to comply with certain shareholder requirements. In practice this translates into a minimum number of shareholders and/or a maximum percentage owned by a single shareholder. The requirements differ greatly between countries. Finally, in some European countries, REIT candidates are required to be listed in public stock exchanges.

As can be seen, REITs and REOCs operate in very different operational environments. REITs have the benefits of attracting investors with their tax transparency, whereas REOCs have more operational freedom and flexibility.

The combined value of all real estate assets in Europe is estimated to amount to 7,800 billion dollars, the respective figure in the US reaching close to 5,9 billion (Table 1). The largest real estate countries in Europe are the UK, Germany and France, in this order. The number of listed real estate companies for all Europe is 366, of which 227 are listed in one of the aforementioned large real estate countries.

Of the 366 listed real estate companies nearly two thirds are set up as REOCs (239 companies) and a third as REITs (127 companies). The combined value of REOCs adds up to 167 billion (67\%) and the respective value of REITs to 82,3 billion dollars (33\%). The overall value of European listed real estate is no more than 249 billion dollars, or $3.19 \%$ of total real estate assets. The total European stock market value marked at 11,100 billion dollars, and the listed real estate's share (249 billion dollars) constitutes only $2.24 \%$ of the figure. Despite the recent developments in the European public real estate markets, the figure is still markedly lower than in the US or globally (EPRA, 2009 and EPRA, 2010).

Given that these both forms of investment exist to invest in real estate, any reason for investor preference should lie in the differences regarding regulations (taxes, permissible activities). While many would identify corporate taxation as the primary difference, the ability to pursue growth with internally generated funds is also of importance. In fact, Chan et al. (2003) posit the REIT form being a disadvantage for any firm wanting to adopt a highgrowth strategy. REOCs' ability to retain earnings allows greater growth opportunities without additional external funding. Since growth is generally positively related to shareholder returns, investors should prefer REOCs to REITs based on this factor (Delcoure and Dickens, 2004). Moreover, Delcoure and Dickens argue that the retained earnings could be profitably used to hire outside management to decrease possible principal-agent problems. The authors conclude by noting that the superior form of the two would be the one providing the best combination of growth opportunities and management interest alignment with shareholders, with a minimum risk. 


\section{LITERATURE REVIEW}

The issue of listed real estate in a mixed-asset portfolio has been a widely researched topic in the academia thus far. However, it should be noted that the majority of the studies carried out using US data only concern REITs, and not REOCs. On the contrary, the European studies mainly address issues regarding REOCs, and not REITs. The natural reason for this disparity observed between the two continents is that the REIT vehicle was introduced in the US already in the $1960 \mathrm{~s}$, whereas REOCs in the US market have been a somewhat scarcer vehicle. Conversely, REITs constituting a relatively new form of investment, REOCs have traditionally been the dominant form of real estate investment in Europe.

According to Brounen et al. (2009b), the increasing international popularity of real estate as an asset class reflects the perceived diversification benefits of property in a mixed-asset portfolio. The earlier research on real estate as a portfolio diversifier suggests that the private and public real estate assets have a place to them in a mixed-asset portfolio (Feldman, 2003). Chiang and Lee (2002) analysed REIT returns using international multi-asset data from 1975-1997, concluding that REITs are unique in nature and their returns at the macro level cannot satisfactorily be duplicated by investing in other asset types. The researchers continue by adding that practitioners should treat REITs as an asset class per se, and include REITs in a multi-asset portfolio even when investing in unsecuritized real estate is a viable investment. These propositions are supported by a later study by Brounen and Eichholtz (2003) who find property shares providing increased mixed-asset diversification potential (US and UK data from 1986-2002). Employing US data from 1984-2002, Lee and Stevenson (2005) assert that REITs are consistently providing diversification benefits to the mixedasset portfolio. Furthermore, the diversification benefits available in international securitized real estate are documented in various sources (eg. Hamelink and Hoesli, 2004).

Ooi et al. (2007) note that the performance and pricing of REIT stocks is a topic attracting the wide interest of both academics and practitioners. The earlier research on the issue, often performed using the US data, provides indications that the performance of REIT vehicles and the relationship of those vehicles to other asset classes have not been stable, but rather evolved with the development of the sector. Empirical studies have demonstrated the REIT sector going through a dramatic change in the early 1990s (Chong et al., 2009): Having been segmented from the broader equity market and behaving more like fixed income assets during the time period 1972-1991, from 1992 onwards (known as the new REIT era, as in Clayton and MacKinnon, 2001), the REIT market has been integrated into equity markets and has started to behave more like stocks (Glascock et al., 2000). The results of Clayton and McKinnon (2001) give support to this perception: It is argued that this shift can, at least to some extent, be attributed to the fact that the REIT sector is maturing as reflected by the number of shares traded annually. Moreover, the researchers find that the sensitivity of REIT returns to large-cap stocks has declined with time; on the contrary, the sensitivity to small-cap stocks has increased. These findings are also supported by a study by Stevenson (2002): In general, the REIT sector is increasingly influenced by volatility in small-cap and value stocks. Stevenson posits that given the nature, average size and asset base of REITs, these results come as no surprise.

REIT correlation to equity returns has been exhibiting a positive trend (Chong et al., 2009). Utilizing a US data set from 1990-2005, the researchers studied the temporal variations in conditional correlations between REIT returns and equity, bond and commodity returns. They found that while REIT correlations to bonds 
and commodities fell, correlations between REITs and equity returns rose over the period analyzed. Furthermore, for equity and bond benchmarks, correlations with REITs rose especially during the periods of above-average volatility.

As discussed, the vast majority of the preceding research on public real estate returns has typically been focused on analyzing either REITs or REOCs, not both. However, Delcoure and Dickens (2004) made an exception: As the most universally accepted investment advice is to diversify, they asked how the diversification benefits between these two optional forms of securitized real estate investments differ (if they do).

Even though both REITs and REOCs invest almost exclusively in real estate related assets, REITs and REOCs seem to have different systematic risk levels: The authors claim REOCs exhibiting higher levels of systematic risk. Thus, ceteris paribus, REITs should provide better diversification possibilities.

Dhar and Goetzmann (2005) further contribute by bringing another perspective to the issue: In addition to relative return performance and the qualities of real estate as portfolio diversifiers in a mixed-asset portfolio, investors in international property shares are also concerned with liquidity. In addition to the risk of poor management and lack of reliable valuation, liquidity risk is even hypothesized being the primary risk factor in direct real estate investment. A host of research has been processed on the co-movement of asset prices, returns and volatilities across international markets, but the role of liquidity in international stock markets has been underresearched (Dhar and Goetzmann, 2005).

Hameed et al. (2010) suggest that negative market returns have been documented to decrease stock liquidity. Consistent with the theoretical models set forth, negative market returns decrease liquidity much more than positive returns increase it. Hameed et al.
(2010) note that, among others, similar observations regarding market development and liquidity have been documented by Brunnermeier and Pedersen (2009), Garleanu and Pedersen (2007), Vayanos (2004), Morris and Shin (2004), Bernardo and Welch (2004) and Gromb and Vayanos (2002). The exact details of the above studies differ, but they all predict that large market declines increase the demand for liquidity.

According to Benveniste et al. (2001), enhancing liquidity is one of the avenues through which management can increase equity value. Already since Amihud and Mendelson (1986), one goal of finance literature has been determining a link between the value of equity and its underlying liquidity. In terms of the price impact of trades (US REIT data 1993-1996), Clayton and McKinnon (2000) documented strong evidence of increased REIT liquidity. However, Bertin et al. (2005) propose that the price-impact of trades is more drastic for REITs than for non-REIT stocks.

\section{DATA AND METHODOLOGY}

The purpose of this paper is to study the European REOC and REIT liquidity and performance, focusing on the potential differences in REOC and REIT characteristics. As discussed, the history of European REITs is yet rather short, the first index measuring REIT market development was not introduced until March 2006. However, the primary interest being directed to the relationship of REOCs and REITs, and not nominal long term returns, a study period of close to 1200 trading days is judged to constitute a large enough sample.

The data is gathered from 10.3.2006, the index base date for the FTSE REIT/Non-REIT indices used in the study. Sampling period being one day, the final observation date is 30.06.2010. The broad stock market went through a serious down cycle during the study period: Therefore again, of primary interest 
are the relative characteristics of REOCs and REITs (and other assets), not the nominal values the variables have been exhibiting per se.

The data used in this study is retrieved from Thomson Datastream, FTSE Index Company and European public real estate association (EPRA). For REIT market in Europe, the FTSE EPRA/NAREIT Developed Europe REITs Index constructed by FTSE Index Company was used. For REOCs, the FTSE EPRA/ NAREIT Developed Europe Non-REITs Index was employed, respectively. The REIT index is comprised of 37 and REOC (non-REIT) index of 41 real estate equities. Of the 37 REIT index constituent equities, 25 are quoted in Euros and 12 in UK Sterling. On the REOC side only 14 equities are quoted in Euros, whereas the figure for Sterling is 16, Swedish Krona 6, Swiss Franc 4 and Norwegian Krona 1. Moreover, the index constituents are screened for appropriate free float and share liquidity. The index currency is Euro.

The FTSE EPRA/NAREIT Developed Europe REITs Index is a subset of the FTSE EPRA/NAREIT Developed Index, which gives investors the capability to view each constituent's classification within the EPRA/NAREIT universe according to REIT legislation.

The benchmark equity indices used are MSCI Europe, MSCI Europe Value, MSCI Europe Growth, S\&P500 Composite and. All equity indices used in the study are quoted as total return indices.

Sample statistics for asset returns and volatilities are summarized in Table 4. REIT, REOC and European benchmark stock index development is graphed (Figure 1). Pearson correlation coefficients are calculated for the whole study period and a complete correlation matrix is formed (Table 5).

Rolling analysis was applied in this study when scrutinizing the issue of real estate stock liquidity in accordance with general stock market development and volatility. A rolling anal- ysis of a time series model is often introduced to assess the stability of a model over time. When analyzing time series data, a key assumption is that the parameters of a model are constant over time. However, due to changes in the economic environment, this assumption may be questionable: A general technique to scrutinize the constancy of the parameters of a model is to compute parameter estimates over a fixed sized rolling window through the sample. In this paper rolling analysis has been used by calculating 50 day rolling averages for the variables studied.

Two different liquidity measures are applied to test liquidity: daily euro trading volume and daily turnover ratio. Euro trading volume is a product of the amount of stocks traded multiplied by the stock price; daily turnover ratio is reached when the amount of stocks daily traded is divided by the number of all shares outstanding.

It should be noted that trading volume can be measured either using daily euro trading volume or plainly trading volume, which would implicate the number of shares traded. Interpreting the liquidity graphs one might draw a conclusion that the euro trading volume (being a product of the number of shares traded multiplied by the share price) naturally rises with rising stock market; however, this is not the case as we cannot expect the number of shares being traded to be constantly independent of the market environment. Therefore, in order to give a clear image of the value of daily trading, the daily euro trading volumes are preferred.

\section{EMPIRICAL RESULTS}

In this section the empirical results of the study are discussed, and the overall study period and annual returns, volatilities, liquidity and asset correlations are provided and analyzed. 


\subsection{Asset returns and volatilities}

The development of both real estate stocks (REITs and REOCs) over the study period was inferior to those of all benchmark indices (see Table 4). The general European stock market (MSCI Europe) decreased by $2.72 \%$ annually, but the REITs did even worse by depreciating with $9.68 \%$ per year. REOCs did not do well either with an annual return of $-14.07 \%$. The best return, or de facto smallest loss, was exhibited by the European growth stocks $(-0.98 \%$ p.a.) topping S\&P500 Composite (-2.82\% p.a.) and European value stocks ( $-5.98 \%$ p.a.). A graphical representation is provided for the indexed development of REITs, REOCs and the general European stock market in Figure 1: Since July 2007 the general index started outperforming the real estate indices, a pattern that has been unchanged until the end of the study period.

Real Estate stocks not only produced the lowest returns, but also exhibited the highest volatility figures in the study group. The growth stocks displayed an annual volatility of $21.84 \%$ (lowest in the group), whereas the respective figure of REOCs was $27.20 \%$ and that of REITs $29.57 \%$. General European stock market volatility stood at $23.93 \%$, being significantly lower than that of real estate stocks.

REITs have exhibited lower figures of depreciation (i.e. superior returns) than REOCs, but in terms of volatility REOCs have had the upper hand. However, the discrepancies are not of similar magnitude: the higher returns exhibited by REITs clearly more than match the respectively higher volatility. Ceteris paribus, if measured e.g. using the Sharpe ratio, REITs would explicitly make a more lucrative investment asset.

Table 4. Asset returns for the holding period; also annual returns and volatilities are provided

\begin{tabular}{llll}
\hline & $\begin{array}{l}\text { Holding } \\
\text { period } \\
\text { return }\end{array}$ & $\begin{array}{l}\text { Annual } \\
\text { return }\end{array}$ & $\begin{array}{l}\text { Annual } \\
\text { volatility }\end{array}$ \\
\hline REITs & $-36.2 \%$ & $-9.7 \%$ & $29.6 \%$ \\
REOCs & $-48.8 \%$ & $-14.1 \%$ & $27.2 \%$ \\
MSCI & $-11.5 \%$ & $-2.7 \%$ & $23.9 \%$ \\
Europe & & $-6.0 \%$ & $27.7 \%$ \\
MSCI & $-23.8 \%$ & & \\
Europe & & $-1.0 \%$ & $21.8 \%$ \\
Value & & & \\
MSCI & $-4.3 \%$ & $-2.8 \%$ & $26.0 \%$ \\
Europe & & & \\
$\begin{array}{l}\text { Growth } \\
\text { S\&P500 }\end{array}$ & $-11.9 \%$ & & \\
Composite & & & \\
\hline
\end{tabular}

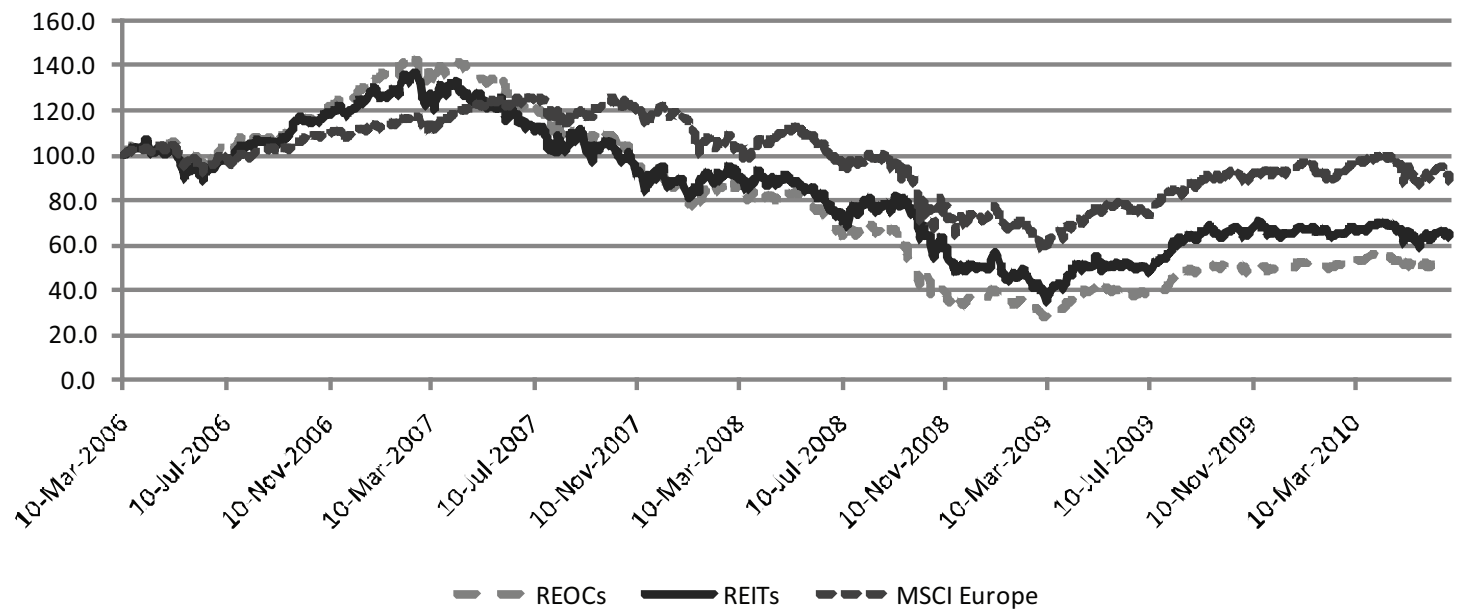

Figure 1. Indexed asset returns for REITs, REOCs and the general stock market (MSCI Europe Index) 


\subsection{Asset correlations}

Inter-asset correlations amongst REITs, REOCs and major European stock indices as well as the S\&P 500 Composite index are provided in Table 5. The daily development of real estate stock values was compared to that of the benchmark indices, and some interesting findings were made.

When looking at the correlation figures among REITs/REOCs and other assets, we find patterns where REITs correlate somewhat strongly with most equities, correlation coefficients ranging from 0.46 (S\&P500) to 0.77 (Europe value stocks). Quite on the contrary, the development of REOCs seems to be rather independent of the development of benchmark indices, correlation coefficients ranging from 0.13 (REITs and Europe value stocks) to 0.33 (S\&P500).

Looking at Figure 1, one would assume a correlation coefficient for REITs and REOCs higher than 0.13. Therefore, the potential existence of cross-correlation among REITs and REOCs was tested. A cross-correlation test was conducted to study whether a leadlag-relationship was to be found and whether we could document a relationship where the development of one variable (leading) would predict the development of the other variable (lagging).

The results of the test were of help to explain the low correlation of REITs and REOCs (0.13). As observable in the graph (Figure 2),

Table 5. Asset correlation matrix for real estate stocks and other equities

\begin{tabular}{|c|c|c|c|c|c|c|}
\hline & REITs & REOCs & $\begin{array}{l}\text { MSCI } \\
\text { Europe }\end{array}$ & $\begin{array}{l}\text { MSCI } \\
\text { Europe V }\end{array}$ & $\begin{array}{l}\text { MSCI } \\
\text { Europe G }\end{array}$ & S\&P500 \\
\hline REITs & 1.00 & 0.13 & 0.75 & 0.77 & 0.73 & 0.46 \\
\hline REOCs & & 1.00 & 0.14 & 0.13 & 0.14 & 0.33 \\
\hline $\begin{array}{l}\text { MSCI } \\
\text { Europe }\end{array}$ & & & 1.00 & 0.98 & 0.97 & 0.60 \\
\hline $\begin{array}{l}\text { MSCI } \\
\text { Europe } \\
\text { Value }\end{array}$ & & & & 1.00 & 0.94 & 0.59 \\
\hline $\begin{array}{l}\text { MSCI } \\
\text { Europe } \\
\text { Growth }\end{array}$ & & & & & 1.00 & 0.59 \\
\hline $\begin{array}{l}\text { S\&P500 } \\
\text { Composite }\end{array}$ & & & & & & 1.00 \\
\hline
\end{tabular}

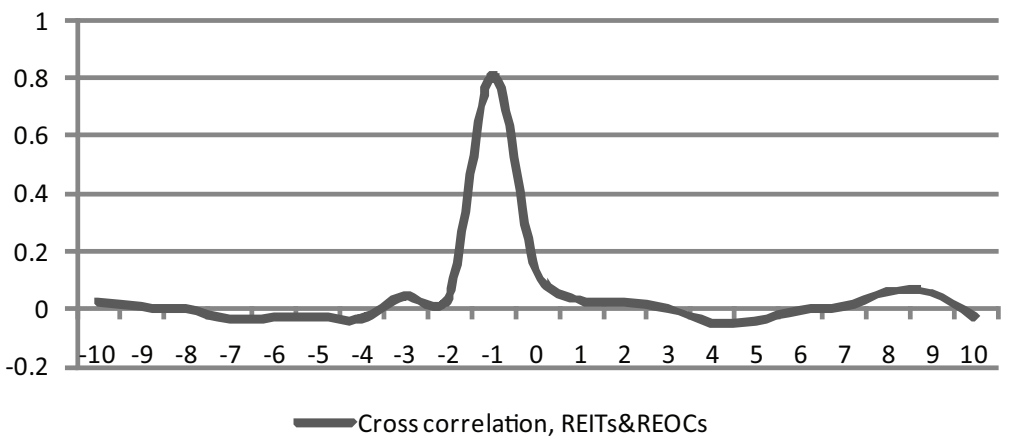

Figure 2. Cross correlation for REITs and REOCs 
a clear pattern of cross-correlation between REIT and REOC returns is found; it seems that the highest correlation (0.81) is given by a combination of returns where REOCs lead REITs by one day. In other words, the REOC returns from day 1 correlate with, or predict, the REIT returns of day 2. Therefore, even though the simple Pearson's correlation test indicates low correlation, the real estate stocks de facto correlate with each other rather strongly. Not only is this finding interesting from a scientific point of view, but it also carries significant implications for practitioners. In order to get the optimal portfolio weightings correct, portfolio managers should be aware of the lead-lag relationship found among these real estate stocks.

After observing the lead-lag relationship between REIT and REOC returns, the crosscorrelation between REOCs and other benchmark equities was also tested. The results show that the REOC returns were also leading the returns of benchmark equities by one day. Adjusting for this pattern, the correlation coefficients for REOCs and benchmark equities ranged between 0.43 and 0.73 . This lead-lag relationship for REOCs and benchmark equities is similar to that observed between REITs and REOCs.

The results imply that even though real estate equities correlate relatively strongly to benchmark equities, the comparative correlations across the benchmark assets themselves are markedly higher. For example, the European equity indices (general, growth, value) all exhibit correlation coefficients between 0.94 and 0.98. In that sense, both forms of real estate stocks (with below-average equity correlation) constitute an interesting investment option in a mixed-asset portfolio environment. However, as suggested by Falkenbach (2009), correlation structures might not be among the primary factors defining market selection when comparing international real estate investments.

\subsection{Liquidity of real estate assets}

Figures 3 and 4 demonstrate the relationship between REOC and REIT stock market development and the changes in real estate stock liquidity as measured by euro trading volume. The indexed euro trading volumes are almost identical replicas of each other, i.e. respective euro trading volumes behave in a similar manner over time. It seems that the real estate stock liquidity is somewhat bound to imitate the stock market development; euro trading volumes for both REITs and REOCs reach their top levels when the stock market tops. Similarly, as the market starts moving downward, the liquidity seems to follow suit. Similar results have been observed in the general stock market e.g. by Hameed et al. (2010).

When comparing the liquidity of REOCs and REITs in terms of stock turnover ratio, a distinct discrepancy is found. During the studied period, REITs exhibit a turnover that is, on average, $30 \%$ superior to that of REOCs (Figures 5 and 6). Given that the liquidity risk might not be nearly as inherent in listed real estate investment as in the private market, this discrepancy was deemed remarkable. As described in section 2, REIT as an institution is far more regulated than REOC; REIT holdings are typically limited to $10 \%$ of the shares/owner. Superior REIT liquidity could thus be explained by a more scattered ownership structure and a smaller influence of large blockholders' trading, respectively.

To further study the liquidity characteristics of real estate stocks, the effects of general market volatility on changes in REIT and REOC stock liquidity were analyzed (Figure 7).

Surprising was a fact that from the beginning of the study period until December 2008 liquidity seems to be correlating strongly with market volatility. Increased volatility has resulted in increased liquidity, in terms of both euro trading volumes and turnover ratios. 


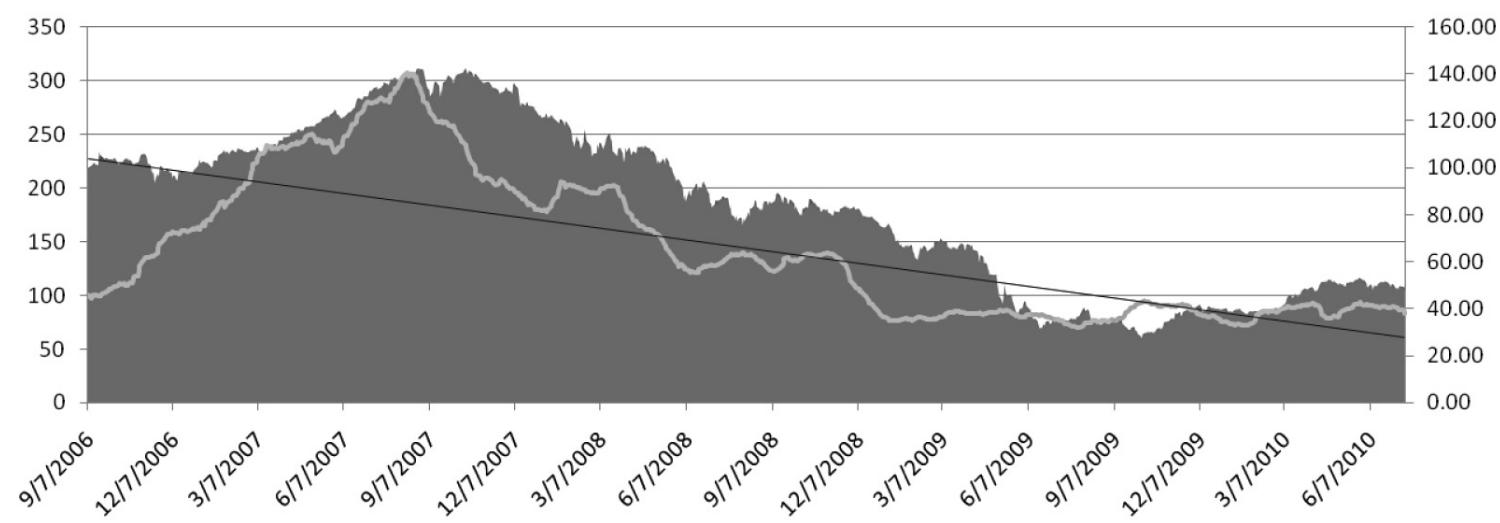

REOC Index — REOCs, Euro Trading Volume, 50-day rolling Index — Linear (REOCs, Euro Trading Volume, 50-day rolling Index)

Figure 3. REOC index development and indexed euro trading volumes

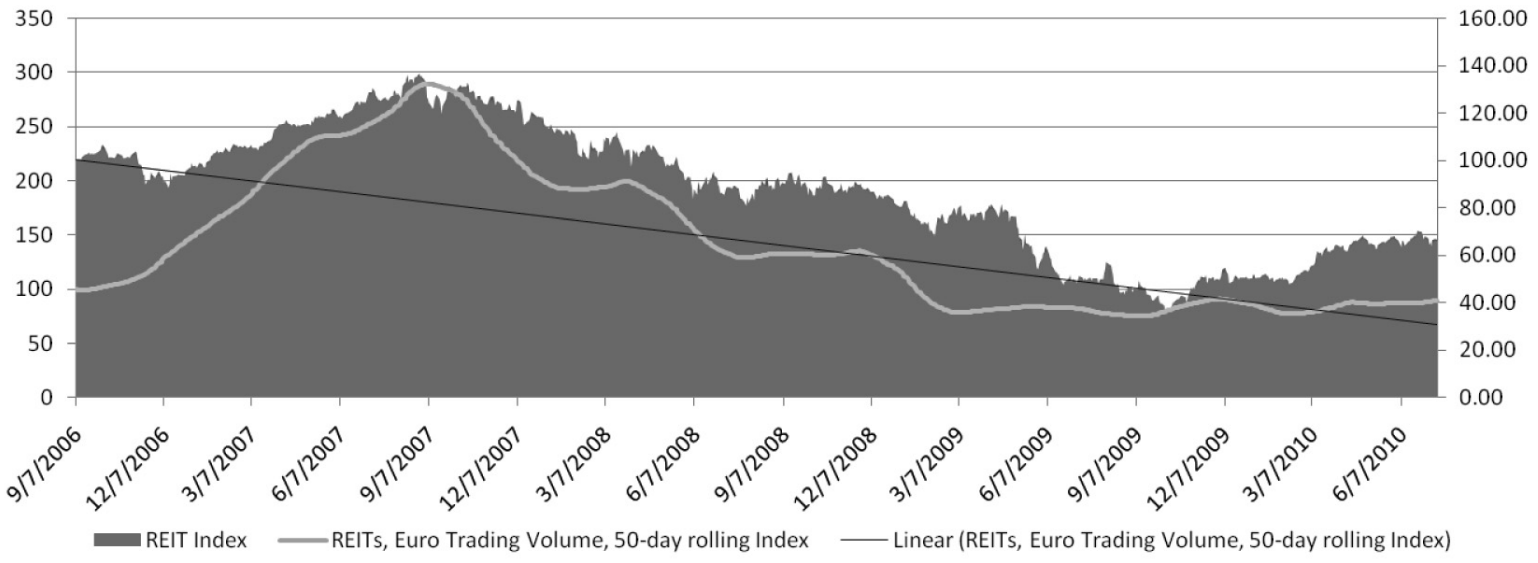

Figure 4. REIT index development and indexed euro trading volumes
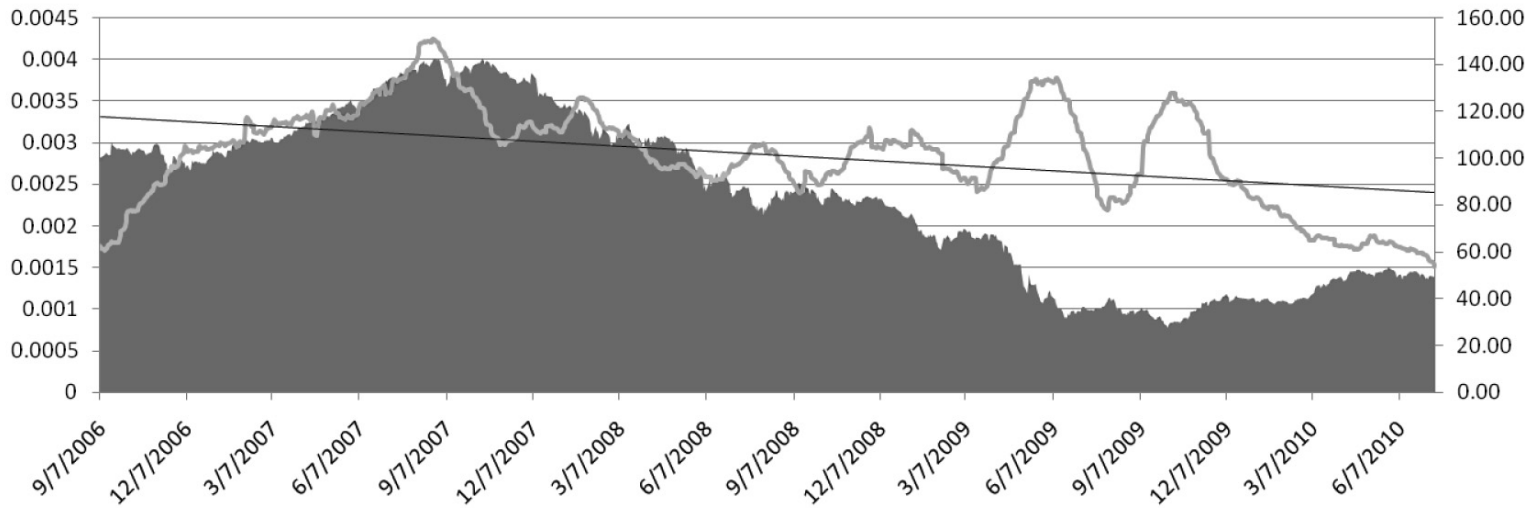

REOC Index _ REOCS, turnover ratio, 50-day rolling average _ L Linear (REOCS, turnover ratio, 50-day rolling average)

Figure 5. REOC index development and asset turnover ratio 


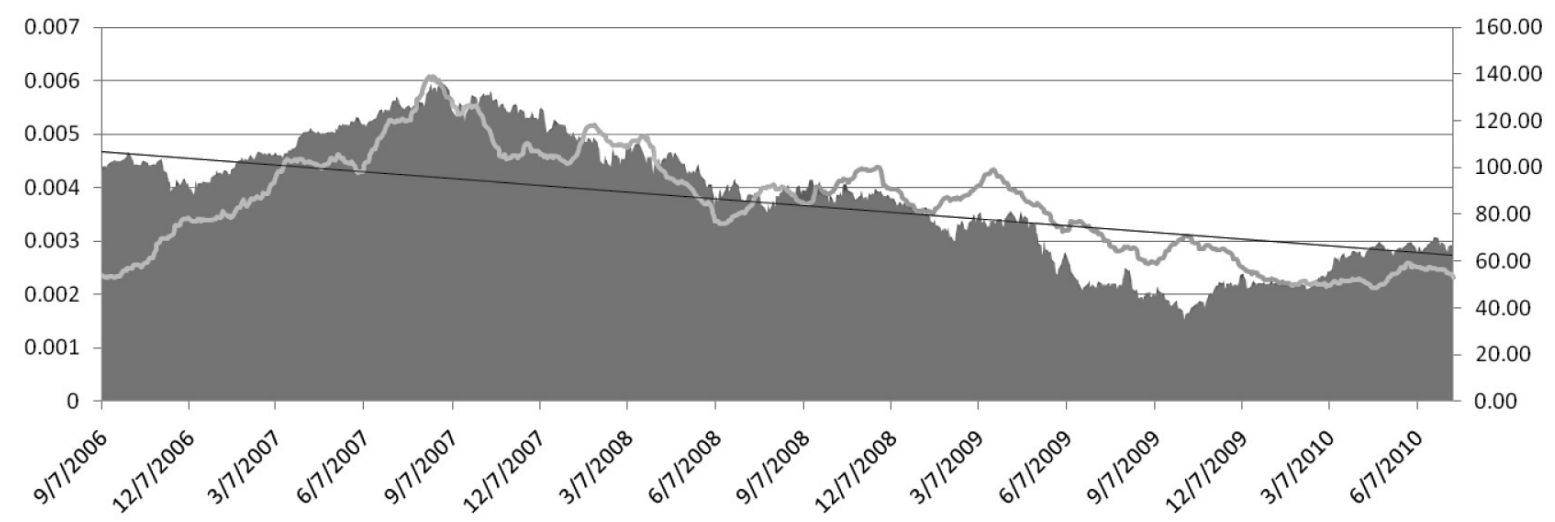

REIT Index _ _ REITs, turnover ratio, 50-day rolling average _ _ Linear (REITs, turnover ratio, 50-day rolling average)

Figure 6. REIT index development and asset turnover ratio

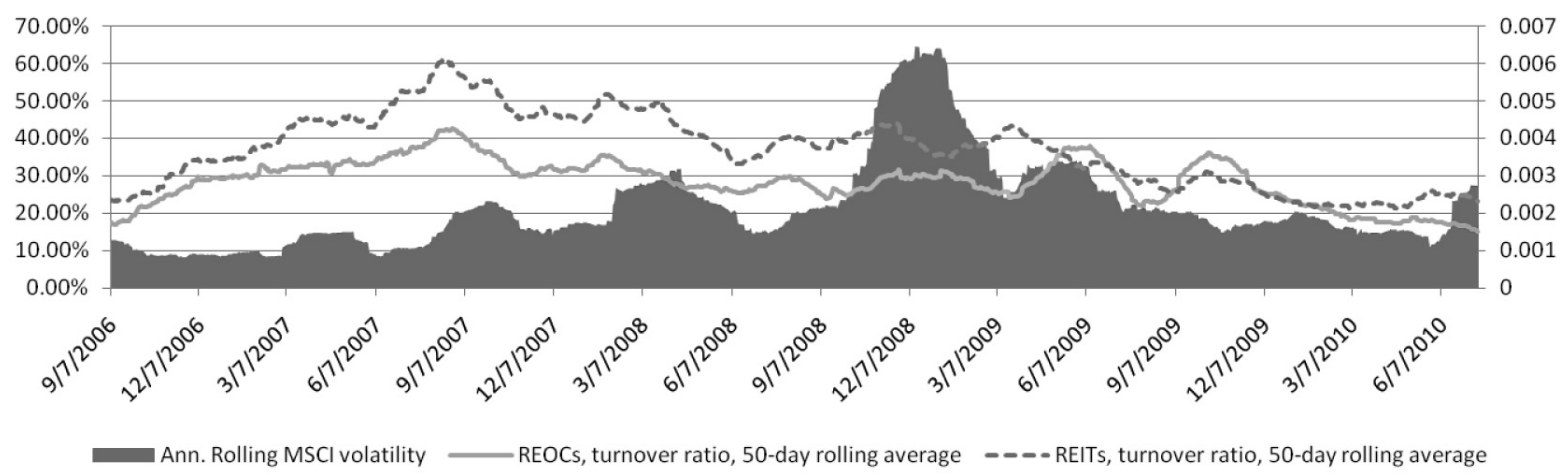

Figure 7. Market volatility and real estate asset turnover ratios

However, from 2009 onwards, the relationship seems somewhat blurred; no clear relationship is detectable. Overall, since July 2007, a downward-trend has been observable in real estate stock liquidity. This trend could help to explain the change in the relationship of volatility and liquidity in the post 2009 data.

\section{SUMMARY AND CONCLUSIONS}

Listed real estate companies can be divided into two categories - real estate operating companies (REOCs) and real estate investment trusts (REITs). The differences pertain to permissible activities and taxation, which could have implications to the performance of the instruments. The REOCs being the traditional form of listed real estate investments in Europe, REITs are a relatively new phenomenon.

Most of the European REIT legislation has been enacted in the past ten years. In the meantime, the European listed real estate market has been expanding rapidly. The number of listed real estate companies for all Europe is 366, of which two thirds (239 companies) are organized as REOCs and a third as REITs (127 companies).

This paper studied the relationship and relative characteristics of these two vehicles. A host of research has been performed studying either of these vehicles, REOCs or REITs, 
whereas this paper is the first one to analyze the qualities and potential differences of the two. It has been of primary interest to investigate daily return characteristics; holding period return, volatility, correlations to other equities, and finally, liquidity.

Due to the short history of European REITs, the study period was limited to a down period in the stock market. Therefore, of primary interest were the relative figures exhibited by the studied variables, not their nominal values. The general European stock market exhibited modest depreciation over the study period, but that development still outperformed that of REITs and REOCs. Real Estate stocks not only produced the lowest returns, but also exhibited the highest volatility figures within the study group.

When studying the correlation patterns it was found out that REITs exhibited substantially higher correlations with other equities than REOCs. Even the correlation between REITs and REOCs, vehicles of largely similar nature, was very low (0.13). A potential crosscorrelation pattern among assets was tested: As a result, the daily REOC returns were discovered to lead the daily REIT returns by one day. The correlation for adjusted returns reached a top of 0.81 ; a significant increase from the original correlation of 0.13 . Furthermore, when REOC returns were tested for cross-correlation with other benchmark equities, the results showed that the REOC returns were also leading the returns of benchmark equities by one day. This pattern considered, the adjusted correlation coefficients for REOCs and benchmark equities exhibited significantly higher figures, their levels being comparative to those of REITs and benchmark equities.

Regarding the liquidity of the vehicles, some interesting findings were made. Firstly, the turnover ratio, measuring the ratio of shares of a stock traded during one day, was significantly higher (30\%) for REITs than REOCs. This difference could potentially be explained by limitations regarding REIT ownership structures, thus providing superior liquidity for the stock. Secondly, a notion regarding liquidity: Real estate stock liquidity seems to follow somewhat similar walk than the underlying REOC/REIT stock market development. Liquidity tops are reached when the stock market is peaking and vice versa. Finally, when real estate liquidity and general stock market volatility were studied, it was noted that prior to 2009 the variables seemed to correlate rather strongly, post 2009 totally the opposite was to be observed. Excluding the differing turnover ratios, REOC and REIT liquidity patterns per se were somewhat similar by nature.

The findings imply the following: Even though REITs seem faintly more lucrative than REOCs in terms of asset returns and volatility (combined), findings pertaining to liquidity were of surpassing significance to this paper. Especially the superior stock turnover ratio exhibited by REITs was an interesting phenomenon to be found; this superior figure displayed by REITs could supposedly be a product of legislative ownership restrictions laid on REITs in order to ensure improved liquidity.

In sum, the results of this study suggest that European REITs and REOCs exhibit somewhat similar characteristics in terms of asset returns and volatility, whereas the liquidity tests revealed REITs to be significantly more liquid than REOCs, potentially due to restrictions regarding REIT ownership structure. Ceteris paribus, superior REIT liquidity implies that REITs constitute a preferred investment vehicle. Of interest will be to follow the development of the European listed real estate market and the distinctive features of the studied assets; will the segregation between the studied assets remain the same over time? Or will the relationship change as a product of a maturing European REIT market? How fast will the overall development of the European REIT market de facto be? Is a 
unified European REIT legislation soon to be stipulated and what would the practical implications of such legislation be?

\section{ACKNOWLEDGEMENTS}

The authors wish to acknowledge the financial support of the Academy of Finland (project 122525).

\section{REFERENCES}

Amihud, Y. and Mendelson H. (1986) Asset pricing and the bid-ask spread, Journal of Financial Economics, 17(2), pp. 223-249. http://dx.doi.org/10.1016/0304-405X(86)90065-6

Benveniste, L., Capozza, D. R. and Seguin P. J. (2001) The value of liquidity, Real Estate Economics, 29(4), pp. 633-660. http://dx.doi.org/10.1111/1080-8620.00026

Bernardo, A. and Welch, I. (2004) Liquidity and financial market runs, Quarterly Journal of Economics, 119(1), pp. 135-158.

http://dx.doi.org/10.1162/003355304772839542

Bertin, W., Kofman, P, Michayluk, D. and Prather, L. (2005) Intraday REIT liquidity, Journal of Real Estate Research, 27(2), pp. 155-176.

Brounen, D. and Eichholtz, P. (2003) Property, common stock and property shares - increased potential for diversification, Journal of Portfolio Management, 29(5), pp. 129-137.

http://dx.doi.org/10.3905/jpm.2003.319914

Brounen, D., Eichholtz, P. and Ling, D. (2009a) The liquidity of property shares: an international comparison, Real Estate Economics, 37(3), pp. 413-445. http://dx.doi.org/10.1111/j.15406229.2009.00247.x

Brounen, D., Korsgaard, S. and Mahieu, R. (2009b) The effects of shifting tax regimes: an international examination of the REIT effect, Working paper.

Brunnermeier, M. and Pedersen, L. (2009) Market liquidity and funding liquidity, Review of $\mathrm{Fi}$ nancial Studies, 22(6), pp. 2201-2238. http://dx.doi.org/10.1093/rfs/hhn098

Chan, S. H., Erickson, J. and Wang, K. (2003) Real estate investment trusts: structure, performance, and investment opportunities, New York, NY: Oxford University Press.
Chiang, K. and Lee, M. (2002) REITs in the decentralized investment industry, Journal of Property Investment and Finance, 20(6), pp. 496-512. http://dx.doi.org/10.1108/14635780210446496

Chong, J., Miffre, J. and Stevenson, S. (2009) Conditional correlations and real estate investment trusts, Journal of Real Estate Portfolio Management, 15(2) pp. 173-184

Clayton, J. and MacKinnon, G. (2000) Measuring and explaining changes in REIT liquidity: moving beyond the bid-ask spread, Real Estate Economics, 28(1), pp. 69-115. http://dx.doi.org/10.1111/1540-6229.00794

Clayton, J. and MacKinnon, G. (2001) The timevarying nature of the link between REIT, real estate and financial returns, Journal of Real Estate Portfolio Management, 7(1), pp. 43-54.

Delcoure, N. and Dickens, R. (2004) REIT and REOC systematic risk sensitivity, Journal of Real Estate Research, 26(3), pp. 237-254.

Dhar, R. and Goetzmann, W. N. (2005) Institutional perspectives on real estate investing: the role of risk and uncertainty, Yale ICF Working Paper, No. 05-20.

Eichholtz, P. and Kok, N. (2007) The EU REIT and the internal market for real estate, $A$ Research Report for European Landowners' Organization, the European Property Federation, the Royal Institution of Chartered Surveyors, The European Group of Valuers' Associations, and the Urban Land Institute Europe.

EPRA (2009) Global REIT survey. European Public Real Estate Association - EPRA.

EPRA (2010) Monthly statistical bulletin, July 2010. European Public Real Estate Association EPRA.

Falkenbach, H. (2009) Market selection for international real estate investments, International Journal of Strategic Property Management, 13(4), pp. 299-308. http://dx.doi. org/10.3846/1648-715X.2009.13.299-308

Feldman, B. E. (2003) Investment policy for securitized and direct real estate, Journal of Portfolio Management, 29(5), pp. 112-121. http://dx.doi.org/10.3905/jpm.2003.319912

Garleanu, N. and Pedersen, L. H. (2007) Liquidity and risk management, American Economic Review, 97, pp. 193-197. http://dx.doi.org/10.1257/aer.97.2.193 
Glascock, J. L., Lu, C. and So, R. W. (2000) Further evidence on the integration of REIT, bond and stock returns, Journal of Real Estate Finance and Economics, 20(2), pp. 177-194. http://dx.doi.org/10.1023/A:1007877321475

Gromb, D. and Vayanos, D. (2002) Equilibrium and welfare in markets with financially constrained arbitrageurs, Journal of Financial Economics, 66(2-3), pp. 361-407. http://dx.doi.org/10.1016/ S0304-405X(02)00228-3

Hameed, A., Kang, W. and Wishanathan, S. (2010) Stock market declines and liquidity, Journal of Finance, 3(1), pp. 257-293. http://dx.doi. org/10.1111/j.1540-6261.2009.01529.x

Hamelink, F. and Hoesli, M. (2004) What factors determine international real estate security returns, Real Estate Economics, 32(3), pp. 437462. http://dx.doi.org/10.1111/j.1080-8620 .2004.00098.x

Lee, S. and Stevenson, S. (2005) The case for REITs in the mixed-asset portfolio in the short and long run, Journal of Real Estate Portfolio Management, 11(1), pp. 55-80.

Hoesli, M. and Lekander, J. (2008) Real estate portfolio strategy and product innovation in Europe, Journal of Property Investment \& Finance, 26(2), pp. 162-176.

http://dx.doi.org/10.1108/14635780810857908
Mei, J. and Lee, A. (1994) Is there a real estate factor premium?, Journal of Real Estate Finance and Economics, 9(2), pp. 113-126. http://dx.doi.org/10.1007/BF01099970

Morris, S. and Shin, H. (2004) Liquidity black holes, Review of Finance, 8(1), pp. 1-18. http://dx.doi. org/10.1023/B:EUFI.0000022155.98681.25

Ooi, J., Webb, J. and Zhou, D. (2007) Extrapolation theory and the pricing of REIT stocks, Journal of Real Estate Research, 29(1), pp. 27-55.

Sebastian, S. and Schätz, A. (2010) Real estate equities - real estate or equities?, EPRA Research.

Seiler, M., Webb, J. and Myer, N. (1999) Diversification issues in real estate investment, Journal of Real Estate Literature, 7(2), pp. 163-179. http://dx.doi.org/10.1023/A:1008741320860

Stevenson, S. (2002) An examination of volatility spillovers in REIT returns, Journal of Real Estate Portfolio Management, 8(3), pp. 229-238.

Serrano, C. and Hoesli, M. (2009) Global securitized real estate benchmarks and performance, Journal of Real Estate Portfolio Management, 15(1), pp. 1-19.

Vayanos, D. (2004) Flight to quality, flight to liquidity and the pricing of risk, NBER working Paper. 